\title{
Investigation of Microstructure and Corrosion Resistance of Dissimilar Welded Joint between 304 Stainless Steel and Pure Copper
}

\author{
Sorush Niknamian \\ Ph.D. in Cell and Molecular Biology, CSci (Chartered Scientist), RSciTech (Registered Science Technician), \\ RSci (Registered Scientist) ID: A-0008833, Science Council, United Kingdom and Indiana Cancer Consortium \\ (ICC) certified. \\ Registered Researcher in the U.S. Government's System for Award Management. \\ Registered Scientist at National Center for Biotechnology Information. \\ Medical Student at Liberty University, United States of America, Military Medicine. \\ $B S c$ in Mechatronics Engineering and BSc in applied Mathematics. \\ Board Member of Weston A Price Foundation, Washington, USA \\ so.niknmian@gmail.com
}

\begin{abstract}
Nowadays, welding of dissimilar metals has become significant. In this process, a number of parameters including but not limited to type of electrode, amount of current, preheating temperature, and welding rate, that are essential to be taken into account. For welding of dissimilar metals, various methods are exploited including shielded metal arc welding (SMAW) and gas tungsten arc welding (GTAW). The stimulus for studying welding of $304 L$ stainless steel to pure copper originates from difficulties in joining copper parts of water-circulating molds to their steel part. In this study, the welding is performed on plates of steel and copper using SMAW, GTAW and combined SMAW+GTAW welding methods with EL-CuMn 2, ENiCrMo-6 and ER7OS-4 electrodes. In order to investigate the microstructure and corrosion resistance behavior of welds, the samples were characterized using microstructural study and polarization test. It was observed that among all four welding methods, only combined SMAW+GTAW welding process resulted in successful joint between $304 L$ stainless steel and copper. Both obtained joints possess suitable microstructure and corrosion resistance.
\end{abstract}

Keywords: dissimilar welding; stainless steel; pure copper; combined welding; corrosion resistance

\section{Introduction}

Welding of dissimilar metals has been one of the key topics in the field of welding during past few decades. The existing technological and economical challenges has attracted the attention of researchers to this topic. Numerous works have been done on studying the fusion welding and its characteristics for dissimilar metals [1-4]. Most important parameters in welding of dissimilar metals have been coefficient of thermal expansion, solidification of welded zone, lifetime of welded parts, and thermal fatigue [1]. Welding of two metals (or alloys) with dissimilar chemical compositions is more difficult than two metals with similar chemical compositions [1]. Among the challenges in welding of dissimilar metals, presence of brittle phases, and microstructural segregations are worth mentioning. Reducing the content of intermediate phases in welding metal results in better mechanical properties and corrosion resistance behavior [2]. Spowage et. al. [3] and Tosto et. al. [4] have studied the cracks formation in the zones affected by heat in electron beam welding (EBW) of stainless steel to copper, and microstructure and possible defects, respectively.

GTAW is extensively used in welding of dissimilar metals. Shiri et. al. [5] have studied the effect of filler type in dissimilar welding of 304 stainless steel to copper. Use of copper fillers in dissimilar welding of 304 stainless steel to copper has resulted in improvement of 
mechanical properties of these steels. DIN1753:ES CUSn7 filler is used for welding of lowcarbon steel to copper [6,7]. Nickel-base fillers are nowadays extensively used in dissimilar welding of steel to copper. The reason for using these fillers is to gain improved mechanical properties, higher corrosion resistance, better solid solubility, and absence of intermetallic phases $[8,9]$. Different welding methods such as SMAW and GTAW, and various welding fillers and electrodes have been influential in structural properties and corrosion resistance behavior of dissimilar welding of steel to copper. The aim of this study is to investigate the weldability, and also microstructure and corrosion resistance in dissimilar welding of $304 \mathrm{~L}$ stainless steel and commercial pure copper.

\section{Materials and Methods}

Chemical compositions of 304L stainless steel, pure copper, and the used fillers in welding processes are listed in Table 1.

Table 1. Chemical composition of the used materials. (Wt \%)

\begin{tabular}{|c|c|c|c|c|c|c|c|c|c|c|c|c|c|c|}
\hline & $\mathrm{Nb}$ & $\mathrm{W}$ & $\mathrm{Sn}$ & $\mathrm{O}$ & $S$ & $\mathrm{P}$ & $\mathrm{Cu}$ & $\mathrm{N}$ & $\mathrm{Ni}$ & $\mathrm{Cr}$ & $\mathrm{Mn}$ & $\mathrm{Si}$ & $\mathrm{C}$ & $\mathrm{Fe}$ \\
\hline $\begin{array}{c}\text { Stainless Steel } \\
(304 \mathrm{~L})\end{array}$ & - & - & - & - & 0.03 & 0.045 & - & 0.1 & 12 & 20 & 2 & 0.75 & 0.03 & $\mathrm{Bal}$ \\
\hline Pure copper & - & - & - & 0.06 & - & - & 99.9 & - & - & - & - & - & - & - \\
\hline El-CuMn2 & - & - & 0.8 & - & - & - & Bal & - & - & - & 2.5 & - & - & - \\
\hline ENiCrMo-6 & 1.6 & 1.6 & & - & - & - & - & - & Bal & 13 & 3.5 & - & 0.08 & 7 \\
\hline ER 70S-4 & - & - & - & - & 0.025 & 0.025 & - & - & - & - & $1-1.5$ & 0.85 & 0.15 & - \\
\hline
\end{tabular}

Geometrical and operational parameters of dissimilar welding of 304L stainless steel to pure copper are listed in Table 2.

Table 2. Welding Parameters.

\begin{tabular}{|c|c|}
\hline Type of welding & SMAW, GTAW \\
\hline Voltage & $250 \mathrm{~V}$ \\
\hline Current & $200-140 \mathrm{~A}$ \\
\hline polarity & Reverse \\
\hline Protective gas flow & Argon \\
\hline Tungsten electrode & $\mathrm{W}-2 \%$ Zirconia \\
\hline Thickness of plates & $1 \mathrm{Cm}$ \\
\hline Preheating temperature & $200^{\circ} \mathrm{C}-150$ \\
\hline Joints & $\mathrm{V}$ \\
\hline Angle of inclination & $40^{\circ}-35$ \\
\hline
\end{tabular}

To study the microstructure of studied samples, two different etch solutions are used. The chemical composition of etch solutions used in this study are listed in Table 3. All the samples were studied after etch using an optical microscope, model OLYMPUS PMG3 ${ }^{\mathrm{TM}}$. 
Table 3. Chemical composition of the etch solutions.

\begin{tabular}{|c|l|}
\hline Etch solutions & \multicolumn{1}{|c|}{ Chemical composition } \\
\hline Etch solution Of Copper & $\begin{array}{l}100 \text { to } 120 \mathrm{ml} \text { of water or ethanol+20 ml of } \\
\text { hydrochloric acid }+5 \text { to } 10 \mathrm{gr} \text { of iron chloride III. }\end{array}$ \\
\hline Etch solution Of Stainless steel (304 L) & $\begin{array}{l}10 \text { gr of copper sulfate }+50 \mathrm{ml} \text { of hydrochloric } \\
\text { acid }+50 \mathrm{ml} \text { of distilled water. }\end{array}$ \\
\hline
\end{tabular}

To study the corrosion resistance behavior, individual samples of 304 steel, copper, and welding metal were cut out with dimensions of $1 \times 1 \times 1$, and were tested using a polarization instrument, model BHP2063+, after being immersed in a saline solution $(\mathrm{NaCl} 3 \%)$.

\section{Results and Discussion}

In order to a make a dissimilar joint between 304L stainless steel and pure copper, four different methods were employed which are as the followings:

3.1. Method I: The SMAW method was used as the first method and the consumable electrode for this process was El-Cu- $\mathrm{Mn}_{2}$. Before performing the welding process, the copper plate was preheated to $250^{\circ} \mathrm{C}$ and the welding current was about 140-150 A. In this process, the welding defects such as lack of arc concentration, porosity and slag inclusion were observed. The presence of a basic coating on the electrode led to the slag inclusion in the weld metal. To eliminate this defect, the grinding process is needed which leads to the removal of a significant quantity of the weld metal (Fig.1d).

3.2. Method II: The second employed method was the GTAW process and the used electrode for this process was of El-Cu-Mn2 type (without a basic coating). The preheating temperature for the copper plate in this process was $150{ }^{\circ} \mathrm{C}$ and the welding current was about 180-200 A. This welding process is appropriate for thin metallic plates. If this process is applied to thick plates, sever distortion will occur in these plates due to a high heat input (Fig.1c). The high heat input in this welding process may damage the welding torch.

Method III: The applied process in this method was the combined welding (GTAW+SMAW). In this process, joining was firstly performed by the GTAW process with the El-Cu-Mn2 electrode for the root pass welding and then, the SMAW process with El-Cu-Mn2 basic coated electrode, welding the filling passes was conducted. The preheating temperature of the copper plate was $150{ }^{\circ} \mathrm{C}$ and the welding current was about $220 \mathrm{~A}$ and $120 \mathrm{~A}$ for the GTAW and the SMAW, respectively. After welding, the sample was stress relieved inside a furnace for 2 hours at $200^{\circ} \mathrm{C}$. Applying the combined GTAW+SMAW welding process was appropriate for the dissimilar welding of steel to copper and resulted in a complete joint between steel and copper (Fig.2a).

Method IV: the GTAW+SMAW combined welding process was used in this method. To make a joint, a 5-layered cladding was carried out using EniCrMo-6 nickel base electrode on the copper plate through the SMAW process and then, the GTAW process was employed to make the joint. In this welding process, ER70S-4 was used to obtain a complete joint. The preheating temperature was $200{ }^{\circ} \mathrm{C}$ and the welding current was about $170 \mathrm{~A}$ and $190 \mathrm{~A}$ for the GTAW 
and SMAW processes, respectively. The welded sample was stress relieved at $200{ }^{\circ} \mathrm{C}$ for 2 hours. The cladding of EniCrMo-6 nickel base electrode on the copper plate was appropriate for the dissimilar welding of steel to copper and resulted in the creation of a complete joint between steel and copper (Fig.2 a).

The obtained results from the dissimilar welding of 304L stainless steel to pure copper are shown in Figure. 1.

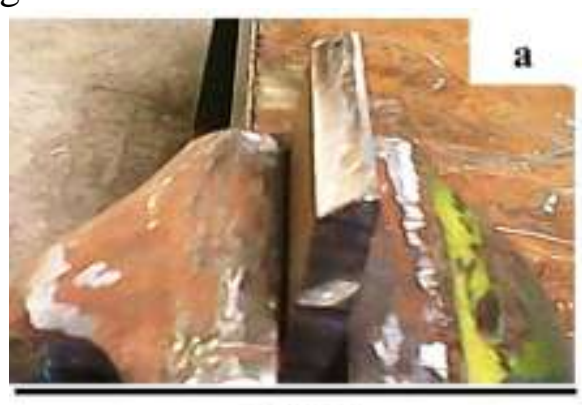

$20 \mathrm{~cm}$

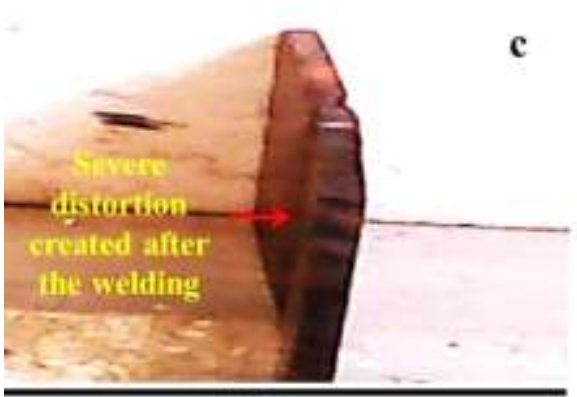

$20 \mathrm{~cm}$

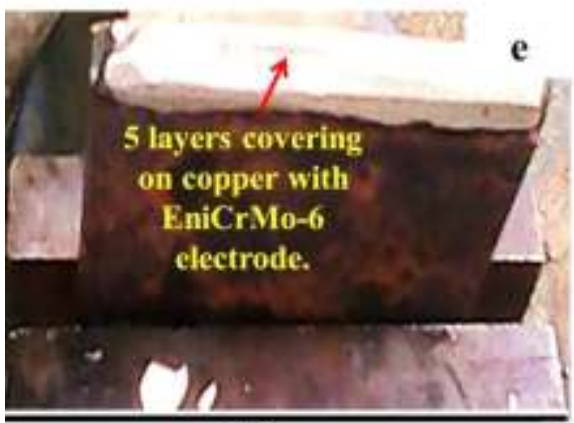

$20 \mathrm{~cm}$

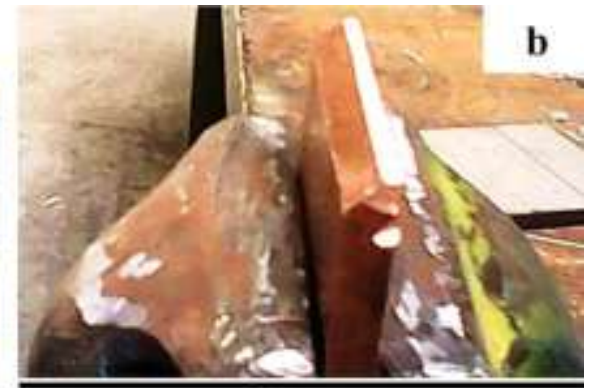

$20 \mathrm{~cm}$

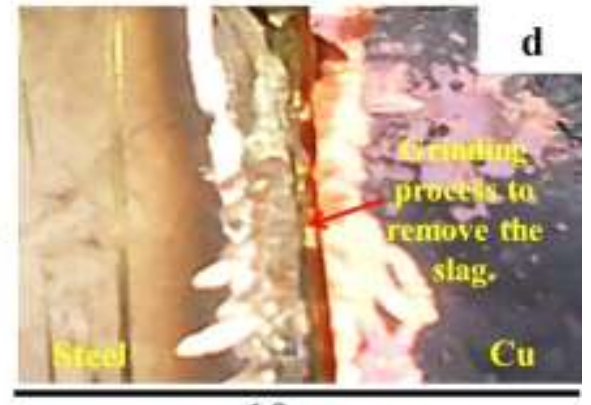

$10 \mathrm{~cm}$

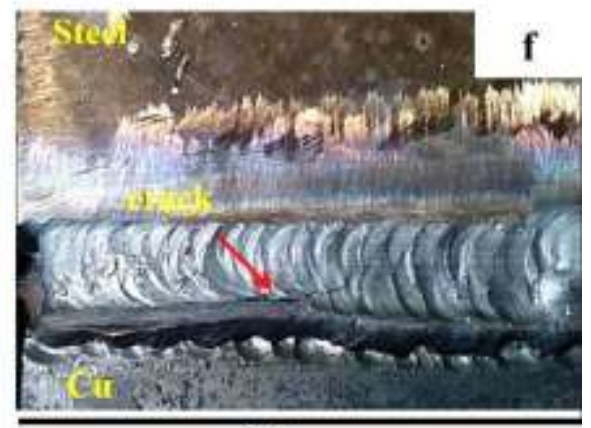

$10 \mathrm{~cm}$

Figure.1. a,b) the view of steel and copper samples beveled at the angles of $35-40^{\circ}{ }^{\circ} \mathrm{C}$ ) severe distortion caused by a high heat input. d) Significant grinding to remove the welding slag. e) The cladding process on copper f) a welding crack in the vicinity of the weld metal in the side of copper base metal.

Figure. 1f shows a welding crack in the vicinity of the weld metal in the side of copper base metal in the SMAW+GTAW combined welding using EniCrMo-6 and ER70S-4 electrodes. Pure copper has a higher heat conductivity compared with 304L stainless steel. During the welding and the solidification of the weld metal, higher heat transfer toward the copper side is done due to its higher heat conductivity which leads to the formation of thermal cracks alongside the weld metal. To inhibit the formation of these cracks, the cladding process 
in five layers by EniCrMo-6 was carried out on copper base metal, after which, no crack was found in the vicinity of the weld metal. The dissimilar joints obtained from methods III and IV are displayed in Figure. 2.

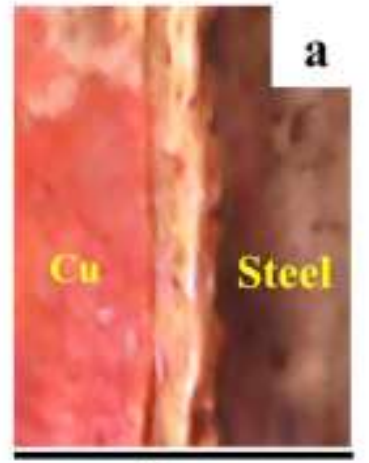

$5 \mathrm{~cm}$

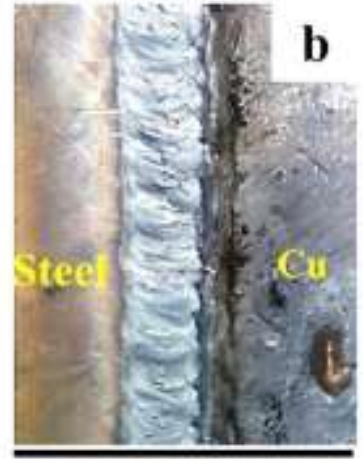

$5 \mathrm{~cm}$

Figure 2. The dissimilar joints obtained from a) method III b) method IV.

The optical microscope (OM) images of different investigated samples are shown in Figure. 3. The resultant microstructures include the solidified steel globules and dendrites in the copper matrix as well as the solidified copper globules in the steel matrix. The copper/steel interface and the steel dendrites in the weld metal are obviously shown in the figures. Also, the solidified dendrites in the weld metal are depicted in Figure. $3 \mathrm{~g}$ and $\mathrm{h}$.

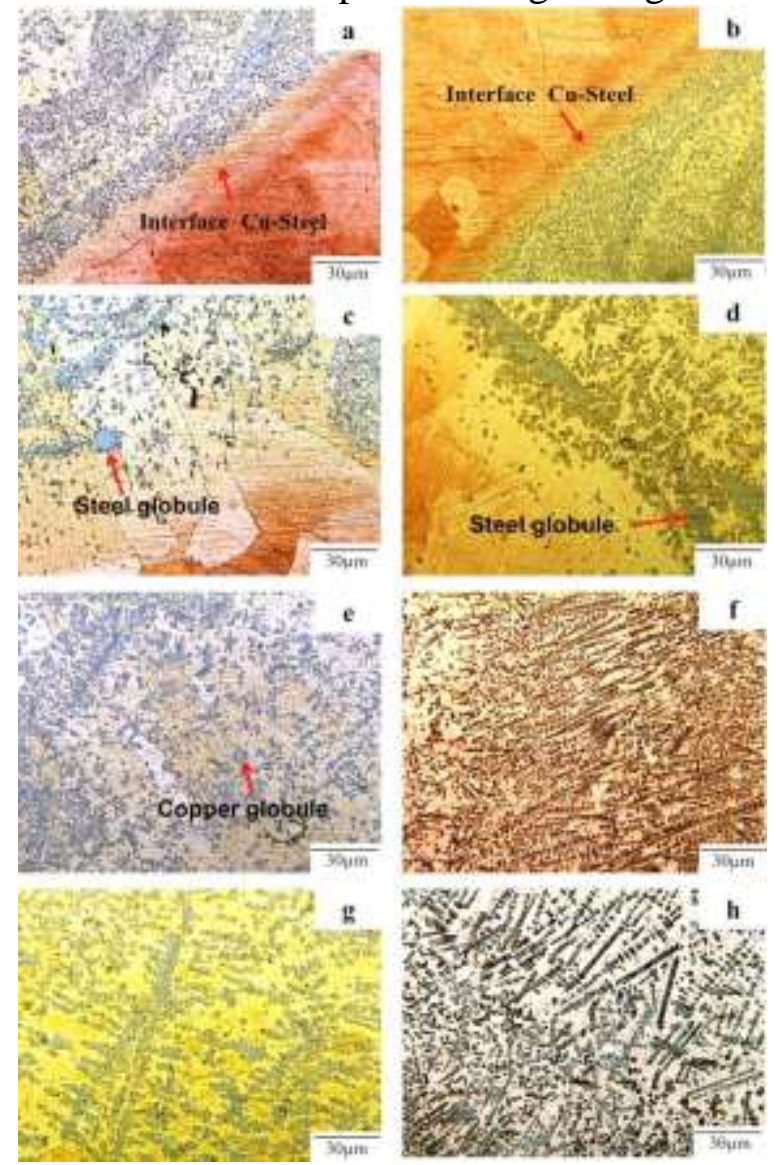


Fig. 3. a) The steel/copper interface in the welding using El-Cu-Mn2 electrode. b) steel/copper interface in welding using EniCrMo-6 and ER70S-4 electrodes. c) the presence of steel globules in the copper matrix in the welding using El-Cu-Mn2 electrode. d) the presence of steel globules in the copper matrix using EniCrMo-6 and ER70S4 electrodes. e) the presence of copper globules in the steel matrix using El-Cu-Mn2 electrodes. f) the presence of steel dendrites in the copper matrix using EniCrMo-6 and ER70S-4. g) the presence of dendrites in the weld metal obtained from the welding using El-Cu-Mn $\mathrm{Mn}_{2}$ electrode. $\mathrm{h}$ ) the presence of dendrites in the weld metal obtained from the welding using EniCrMo-6 and ER70S-4 electrodes.

The metallographic images show that in the GTAW+SMAW combined welding process using El-Cu-Mn $\mathrm{Mn}_{2}$ electrode (method III), the steel and copper globules and dendrites penetrated copper and steel matrix, respectively (Fig. $3 \mathrm{c}$ and e). In a research by Magnabosco et al. [2], they have reported the formation of the same structures in the dissimilar welding of steel to copper. The penetration of steel and copper globules and dendrites in the copper and steel matrices proves the creation of a good joint between 304L stainless steel and pure copper. In the SMAW+GTAW combined welding using EniCrMo-6 and ER70S-4 electrodes (method IV), the solidified copper and steel globules penetrated steel and copper matrices, respectively (Fig. $3 \mathrm{f}$ and d). The presence of these solidified globules and dendrites in the steel and copper matrices indicate the creation of a proper joint between steel and copper [2]. The interfaces of these dissimilar joints are well shown in Figure. $3 \mathrm{a}$ and $\mathrm{b}$.

In order to investigate the effect of the consumable electrodes on the corrosion resistance of the weld metal, the welded samples (the weld metal) and the base metals underwent the polarization test. The results of the polarization test are presented in Figure. 4 and table 5.

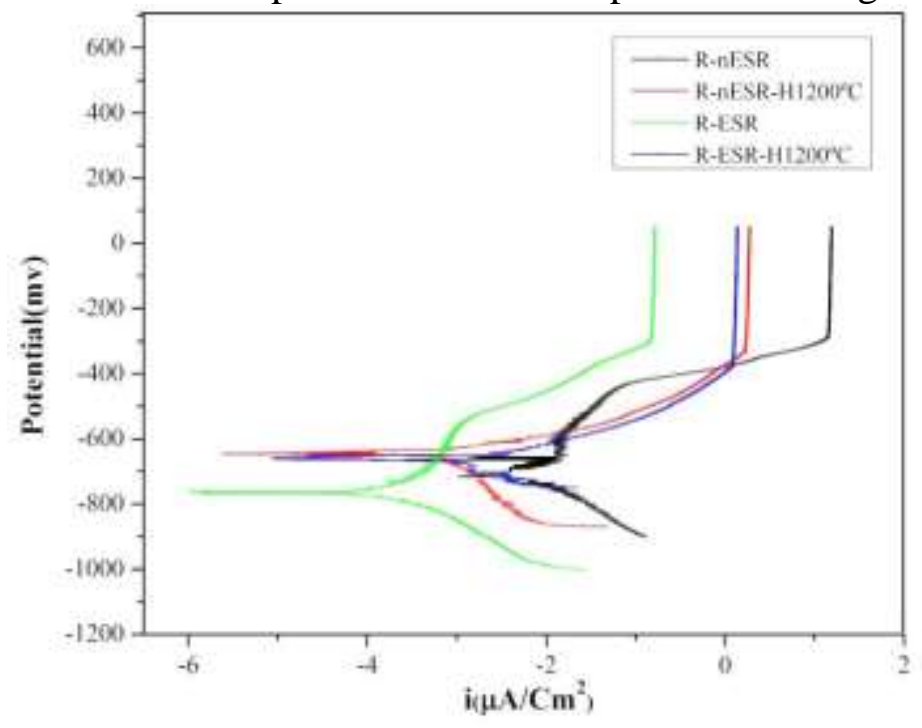

Figure 4. the results of the polarization test to investigate the effect of the consumable electrodes on the corrosion resistance of the weld metals.

Table 5. the results of the Tafel diagrams for the studied samples.

\begin{tabular}{ccc}
\hline & $\mathrm{I}\left(\mu \mathrm{A} / \mathrm{Cm}^{2}\right)$ & potential $(\mathrm{mv})$ \\
\hline Stainless Steel(304L) & 5.07 & -255 \\
Pure copper & 6.95 & -257 \\
EniCrMo-6Er+70S-4 & 7.98 & -621 \\
El Cu Mn 2 & 7.90 & -290 \\
\hline
\end{tabular}


In general, performing the welding process resulted in decreasing the corrosion resistance of the weld metal compared with those of 304L stainless steel and pure copper. Considering the results of the polarization test, EniCrMo6Er+ER70S-4 and El-Cu-Mn 2 electrodes exhibited the same effect on the corrosion resistance of the weld metal and the welding corrosion current for the welded metals using the above-mentioned electrodes were almost equal.

\section{Conclusions}

1. Of the discussed welding processes, only methods III and IV resulted in appropriate joints between 304L steel and pure copper. In these methods, the combined SMAW+GTAW welding process was used using EniCrMo6, ER70S-4 and El-Cu-Mn 2 electrodes.

2. The penetration of copper and steel dendrites and globules into the steel and copper matrices proved the creation of a good joint between 304L stainless steel and copper.

3. El-Cu-Mn $\mathrm{Mn}_{2}$ electrodes which was used in the dissimilar welding of 304L stainless steel to copper exhibited positive effect on the corrosion resistance of the weld metal.

\section{References}

PS Wei, FK Chung. Unsteady Marangoni flow in a molten pool when welding dissimilar metals. Metallurgical and Materials Transactions B. 2000 Dec 1;31(6):1387-403.

Magnabosco I, Ferro P, Bonollo F, Arnberg L. An investigation of fusion zone microstructures in electron beam welding of copper-stainless steel. Materials Science and Engineering: A. 2006 May 25;424(1):163-73.

TA Mai, AC Spowage. Characterisation of dissimilar joints in laser welding of steel-kovar, copper-steel and copper-aluminium. Materials Science and Engineering: A. 2004 Jun 15;374(1):224-33.

S Tosto, F Nenci, H Jiandong, G Corniani, F Pierdominici. Microstructure of copper-AISI type 304L electron beam welded alloy. Materials science and technology. 2003 Apr $1 ; 19(4): 519-22$.

SG Shiri, M Nazarzadeh, M Sharifitabar, MS Afarani. Gas tungsten arc welding of CP-copper to 304 stainless steel using different filler materials. Transactions of Nonferrous Metals Society of China. 2012 Dec 1;22(12):2937-42.

N Kahraman, A Durgutlu. Weldability of 316L stainless steel and copper plates welded by shielded metal arc and tungsten arc welding processes. Technology 2005;8:43-50.

A Durgutlu, N Kahraman, B Gulenc. Joining of copper and steel plates by shielded metal arc and tig welding methods and investigation of their interface properties. J Fac Eng Archi Gazi Univ 2005;20:183-9.

H Sabetghadam, AZ Hanzaki, A Araee. Diffusion bonding of 410 stainless steel to copper using a nickel interlayer. Materials Characterization. 2010 Jun 30;61(6):626-34.

Z Sun, R Karppi. The application of electron beam welding for the joining of dissimilar metals: an overview. Journal of Materials Processing Technology. 1996 May 27;59(3): 257-67. 